\title{
CLINICAL USES OF 2,3-DIMERCAPTOPROPANOL (BAL). IX. THE TREATMENT OF LEWISITE BURNS OF THE EYE WITH BAL ${ }^{1}$
}

\author{
By WILLIAM F. HUGHES, JR. \\ (From the Johns Hopkins University School of Medicine, Baltimore)
}

(Received for publication February 5, 1946)

Exposure of the eye to relatively small quantities of Lewisite liquid or vapor produces a devastating ocular lesion. As will be demonstrated below, the progressive nature of such a burn is caused by the arsenical component of this war gas. To decontaminate the tissues of arsenic after exposure to Lewisite, the English workers (1) synthesized 2,3-dimercaptopropanol $\left(\mathrm{CH}_{2}-\right.$ $\mathrm{SH}-\mathrm{CHSH}-\mathrm{CH}_{2} \mathrm{OH}$ ), the so-called BAL. The work pursued in our laboratories was devoted to the determination of the optimum conditions for the use of this antidote, its mode of action, and limitations. These experiments will be discussed under the following headings: (1) certain clinical and pathologic characteristics of Lewisite burns of the eye relating to mode of action, rate of penetration, and the time at which irreversible histological changes first develop; (2) the rate of penetration and persistence of arsenic in the tissues after Lewisite burns, in relation to the decontaminating action of BAL; and (3) the toxicity and therapeutic efficacy of BAL.

Most of the details of the experiments and a description of the effects of Lewisite on the eye will be reported elsewhere (2). It is the purpose of this communication to summarize the evidence that BAL penetrates rapidly into Lewisite-burned eyes, and competes successfully with toxic arsenical material within the tissues.

\section{Early changes in the ocular tissues after exposure to Lewisite}

During the course of this work, more than 600 rabbit eyes have been exposed to Lewisite. The clinical courses of liquid or vapor burns are essentially similar, and are characterized by rapid tissue necrosis, marked conjunctival and corneal

1 The work described in this paper was done under contract, recommended by the Committee on Medical Research, between the Office of Scientific Research and Development and the Wilmer Institute of the Johns Hopkins University and Hospital. edema, and intense exudation. Immediately on contact with the moist surface of the eye, Lewisite hydrolyzes with the production of an arsine-oxide and hydrochloric acid:

$$
\begin{aligned}
\mathrm{ClCH}=\mathrm{CHAsCl}_{2}+\underset{\mathrm{H}}{\mathrm{H}_{2} \mathrm{O}}= \\
\mathrm{ClCH}=\mathrm{CHAsO}+2 \mathrm{HCl},
\end{aligned}
$$

At the site of contact with the cornea, sufficient hydrochloric acid is liberated to reduce the local $\mathrm{pH}$ below 1.3 as tested by thymol blue. Acidity of this degree is sufficient to produce a localized superficial opacity of the cornea (3), and subsequent treatment with BAL has no effect on this acid component of the Lewisite burn. All of the later progressive characteristics of a Lewisite burn can be produced by the instillation of a dilute solution of Lewisite-oxide, and are therefore attributable to the arsenic component of this war gas. It was also found that a number of other compounds containing trivalent arsenic (e.g., sodium meta-arsenite, phenyl arsine oxide, and mapharsen) were more toxic on intracorneal injection of dilute solutions, than compounds containing pentavalent arsenic (e.g., sodium arsenate and tryparsamide).

Within 10 minutes after exposure to Lewisite and after 30 minutes, histological evidence of damage appears in all tissues of the anterior ocular segment, indicating deep penetration and rapid necrotizing action of this toxic arsenical (Figures 1 and 2).

\section{Rate of penetration and persistence of arsenic in the eyes of rabbits burned with Lewisite}

The rate of penetration and persistence of toxic arsenical material in the cornea and aqueous following exposure to Lewisite were determined, in order to establish time limits during which either a 100 per cent efficient surface decontaminating agent, or an ideal penetrating agent, would be effective, and to study the effect of treatment with 


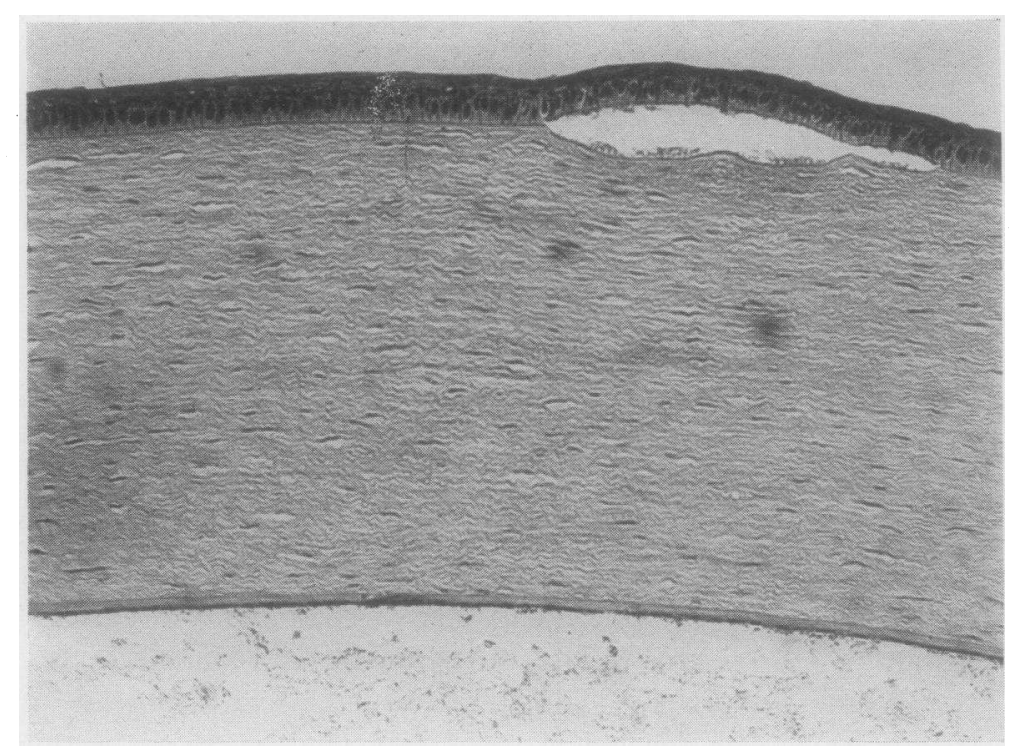

Fig. 1. Section of Rabbit's Cornea, 10 Minutes After Exposure for 30 Seconds to Saturated Lewisite Vapor at $22^{\circ} \mathrm{C}$.

Early changes have taken place in the corneal epithelium which is partially loosened from the underlying stroma. The corneal endothelium is disintegrated, and serum is present in the anterior chamber.

BAL on the persistence of arsenic within the tissues.

\section{MATERIAL AND METHODS}

Rabbit corneas were exposed to Lewisite, either by the instillation of $0.1 \mathrm{mgm}$. of the liquid onto the center of the cornea, or by exposure of the proptosed eye for 30 seconds at $22^{\circ} \mathrm{C}$. to saturated vapor in a Scholz vapor chamber (4). The lids were then closed within $30 \mathrm{sec}-$ onds after exposure. At varying intervals thereafter, the corneas were excised or the aqueous was withdrawn and analyzed for arsenic, according to the method of Chaney and Magnuson (5). With this method, "blank" control tissues may show as much as 0.5 micrograms of arsenic. The experimental error for determination of these small quantities of arsenic is about 10 per cent, but any value over 1.0 microgram indicates a definite presence of arsenic. Since any organic combination of arsenic is converted to inorganic arsenic by this method, the presence of BAL does not interfere with the sensitivity of the test (6).

A second series of experiments was performed to determine the persistence of toxic material on the surface of the cornea, in the cornea, or in the aqueous. Residual toxic material in such burned eyes was detected by transfers to normal rabbit corneas, either by direct contact of the corneal surfaces, by the intracorneal injection of pressedjuice extracts of the corneal stroma, or by the intracorneal injection of aqueous. The reaction in the normal eye produced by the transferred material was then graded according to a numerical evaluation of the symptoms produced, thus giving an index of the toxicity of the material tested.

\section{RESULTS}

Within 2 to 4 minutes after the instillation of liquid Lewisite into the eye followed by closure of the lids, little or no residual toxic material or arsenic remained on the surface of the cornea.

Two minutes after exposure to Lewisite vapor or liquid, from 3.0 to 4.6 micrograms of arsenic were demonstrated within the corneal substance (Table I). The amount of arsenic diminished greatly within the next 30 minutes, and after 11 hours showed only traces of arsenic irregularly, up to 4 days. The urinary excretion of arsenic after the systemic administration of toxic arsenicals has been reported to be very slow, indicating a rather firm attachment of arsenic to the tissues $(7,8)$. Corneal juice continued to be toxic after 1 hour, but was non-toxic after 26 hours (Table II).

Arsenic penetrated into the anterior chamber within $1 \frac{1}{2}$ minutes after the application of liquid 


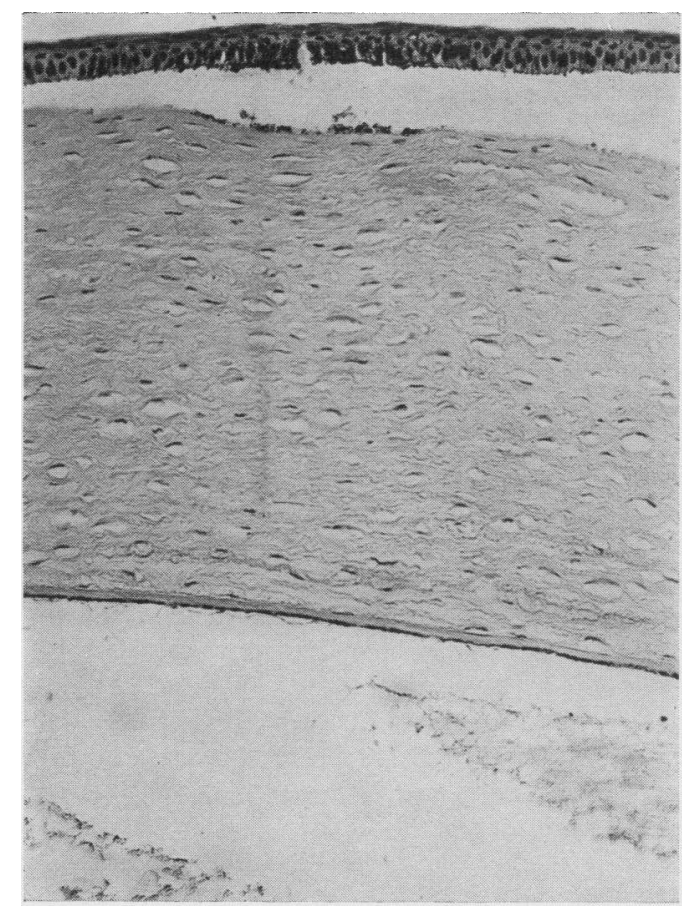

Fig. 2. Section of Rabbit's Cornea, 30 Minutes After Exposure to Lewisite Vapor, Showing Changes in the Cells of the Corneal Stroma

Lewisite to the cornea, and disappeared within 30 minutes after exposure (Table III). The aqueous was found to be toxic at 2 minutes and 10 minutes, but had become non-toxic when tested at 30 minutes.

Surface decontamination after exposure to liquid Lewisite. In view of the evidence above, that Lewisite rapidly disappears from the surface of the cornea and penetrates into the cornea and aqueous, little or no therapeutic effect would be expected from the use of neutralizing agents which do not penetrate into the ocular tissues. Such was found to be the case with 3 types of agents tried: (1) saline irrigation, (2) an iodine-containing solution, so-called "Box I," which will inactivate Lewisite in 15 seconds in vitro, ${ }^{2}$ and (3)

\footnotetext{
2 This solution was devised by Dr. Leslie Hellerman as a method for the continuous regeneration of a limited low concentration of iodine:

$\mathrm{NaI}$

$200 \mathrm{mgm}$. per $100 \mathrm{ml}$

Phosphate buffer pH 7 $\mathrm{M} / 10$
}

Sodium iodoxybenzoate in large excess

Solvent: 50 per cent triacetin, 22 per cent alcohol, and 28 per cent water.
TABLE I

Microchemical analysis of arsenic in cornea following Lewisite burns of the rabbit's eye

\begin{tabular}{|c|c|c|}
\hline Dose of Lewisite & $\begin{array}{l}\text { Time after } \\
\text { application }\end{array}$ & $\underset{\text { arsenic }}{\text { Gamma of }}$ \\
\hline Controls (no Lewisite) & & 0. to 0.5 \\
\hline \multirow[t]{2}{*}{ 0.1_mgm.'liquid } & 2 min. & $\begin{array}{l}6.5 \\
4.1 \\
6.5 \\
4.2 \\
3.7 \\
2.7 \\
4.7\end{array}$ \\
\hline & $\begin{array}{l}30 \text { min. } \\
1 \mathrm{hr} . \\
2 \mathrm{hrs} . \\
4 \mathrm{hrs} \text {. } \\
11 \mathrm{hrs} \text {. } \\
18 \mathrm{hrs} . \\
24 \mathrm{hrs} \text {. } \\
2 \text { days } \\
4 \text { days }\end{array}$ & $\begin{array}{l}1.2 \\
1.6 \\
0.7 \\
2.9 \\
1.3 \\
1.8 \\
0.5 \\
0 . \\
1.7 \\
0.5 \\
0.5 \\
0 \\
0.9\end{array}$ \\
\hline $\begin{array}{l}\text { Saturated vapor } \\
22^{\circ} \mathrm{C} \text {. for } 30 \text { secs. }\end{array}$ & $\begin{array}{l}2 \mathrm{~min} . \\
30 \mathrm{~min} . \\
1 \mathrm{hr} . \\
4 \mathrm{hrs} \text {. } \\
24 \mathrm{hrs} \text {. }\end{array}$ & $\begin{array}{l}2.7 \\
2.9 \\
3.3 \\
1.2 \\
1.9 \\
1.3 \\
0.8\end{array}$ \\
\hline
\end{tabular}

hydrogen peroxide (Table IV). In these experiments, the technique for the production and grading of the standard lesion was that described below for the BAL treatment experiments.

The treatment of Lewisite burns of the eye with $B A L$

Since Lewisite penetrates through the cornea into the aqueous within 2 minutes after exposure, and produces irreversible changes in the tissues

TABLE II

Toxicity of corneal juice after instillation of $0.1 \mathrm{mgm}$. of liquid Lewisite into a rabbit's eye

\begin{tabular}{c|c}
\hline $\begin{array}{c}\text { Time after instillation } \\
\text { of Lewisite }\end{array}$ & $\begin{array}{c}\text { Maximum ocular reaction pro- } \\
\text { duced by intracorneal injection } \\
\text { of corneal juice into normal } \\
\text { rabbit's eye }\end{array}$ \\
\hline 2 min. & 47 \\
30 min. & 30 \\
1 hour & 17 \\
26 hours & 2 \\
27 hours & 2 \\
4 days & 2 (2 injections) \\
\hline
\end{tabular}


TABLE III

Microchemical analysis of arsenic in aqueous following the instillation of $0.1 \mathrm{mgm}$. of Lewisite on the rabbit's cornea

\begin{tabular}{c|c}
\hline Time after instillation of Lewisite & Gamma of arsenic \\
\hline Aqueous control (no Lewisite) & 0.4 (blank of method= \\
0.0 to 0.5 gamma) \\
$\begin{array}{c}\text { Needle control (for surface con- } \\
\text { tamination in withdrawing }\end{array}$ \\
$\begin{array}{c}0.2 \\
\text { aqueous) }\end{array}$ \\
\hline 1 min. & 0.5 \\
1.5 min. & 2.2 \\
5 min. & 2.8 \\
10 min. & $3.2(2$ specimens) \\
30 min. & 3.2 \\
1 hr. & 0 \\
$2 \mathrm{hrs}$. & 0.5 \\
11 hrs. & 0.9 \\
\hline
\end{tabular}

of the anterior ocular segment soon after 10 minutes have elapsed, a successful decontaminating agent must have the capacity to penetrate rapidly and to compete successfully for both free and combined arsenic within the tissues. To obtain maximum therapeutic effect from the local use of BAL after exposure to Lewisite, the following variables were studied: (1) local toxicity of BAL for both normal and Lewisite-burned eye, (2) optimum concentrations of BAL, and techniques of application to the eye, (3) the time limits during which treatment is efficacious, and (4) species differences in toxicity and therapeutic effectiveness of BAL.

\section{MATERIALS AND METHODS}

Preliminary experiments were devoted to the production of a reproducible and uniform standard lesion by Lewisite, the technique and dosage to be used on treatment experiments. In general, it is necessary that the

TABLE IV

Surface decontamination of the rabbit's eye 2 minutes after the instillation of $0.1 \mathrm{mgm}$. of Lewisite

\begin{tabular}{|c|c|c|c|c|}
\hline $\begin{array}{c}\text { Num- } \\
\text { ber } \\
\text { of } \\
\text { eyes }\end{array}$ & Decontaminating agent & $\begin{array}{c}\text { Maximum } \\
\text { ocular re- } \\
\text { action }\end{array}$ & $\begin{array}{c}\text { Final } \\
\text { corneal } \\
\text { opacity }\end{array}$ & Days \\
\hline $\begin{array}{l}3 \\
3 \\
6 \\
3\end{array}$ & $\begin{array}{l}100 \mathrm{ml} \text {. saline irrigation } \\
\text { "Box } \mathrm{I} \text { " (iodine solution) } \\
2 \text { per cent } \mathrm{H}_{2} \mathrm{O}_{2}(3 \text { drops }) \\
\mathrm{Blood} \text { catalase alternating } \\
\text { with } 5 \text { per cent } \mathrm{H}_{2} \mathrm{O}_{2} \text { every } \\
5 \text { secs. for } 1 \text { min. } \\
\text { No treatment }\end{array}$ & $\begin{array}{l}\quad \text { per cent } \\
72(\mathrm{SD}=10)^{*} \\
66(\mathrm{SD}=3) \\
69(\mathrm{SD}=4) \\
63(\mathrm{SD}=20) \\
74(\mathrm{SD}=8)\end{array}$ & $\begin{array}{c}\text { per cent } \\
75(\mathrm{SD}=19) \\
69(\mathrm{SD}=2) \\
65(\mathrm{SD}=6) \\
50(\mathrm{SD}=30) \\
\\
69(\mathrm{SD}=14)\end{array}$ & $\begin{array}{l}7 \\
7 \\
7 \\
7\end{array}$ \\
\hline
\end{tabular}

$* \mathrm{SD}=$ Standard deviation of the mean. lesion be sufficiently severe to guarantee reproducibility, and yet an excessive dosage should be avoided which might mask the efficacy of a therapeutic agent of low potency. Such a threshold lesion was produced by the instillation of $0.1 \mathrm{mgm}$. of liquid Lewisite directly from a micrometer syringe and No. 26 blunt needle either on the limbus or center of the cornea. A somewhat less severe but consistent lesion was produced by exposure of the proptosed eye to saturated Lewisite vapor at 22 to $24^{\circ}$ C. for 30 seconds. The severity of the lesion produced was evaluated numerically by grading the important clinical symptoms elicited by the toxic agent. In order to obtain single values which could be used for statistical comparisons, the acuteness of the reaction was estimated by adding the maximum values for each symptom over the course of observation and conversion of the total, to a percentage figure, the so-called "maximum ocular reaction." An index of persistent corneal damage was obtained by adding the values of the corneal symptoms on the last day of observation, a total of 24 points or corneal perforation representing a 100 per cent lesion.

Preliminary treatment experiments were made with a sample of BAL obtained in the spring of 1942 from Dr. Peters' Laboratory at Oxford. Very little difference in toxicity or therapeutic efficacy could be detected between the British and American (NDR 133 Q-Z) samples of BAL. The American sample appeared to be slightly more toxic at higher concentrations, and more effective at lower concentrations, but the British sample was older at the time of comparison. Subsequent experience with later samples of American BAL has shown results comparable to those reported here for the earlier sample NDR 133 Q-Z.

Suitable solvents for BAL were found in propylene glycol, ethylene glycol, redistilled thiodiglycol and triacetin. BAL is sparingly soluble and deteriorates rapidly in water, but is effective therapeutically in aqueous solution. Because of many practical advantages in applying ointments to the eye, a BAL ointment was devised and prepared by Mr. Robert S. Fuqua, Chief Pharmacist of the Johns Hopkins Hospital, for use in these experiments.

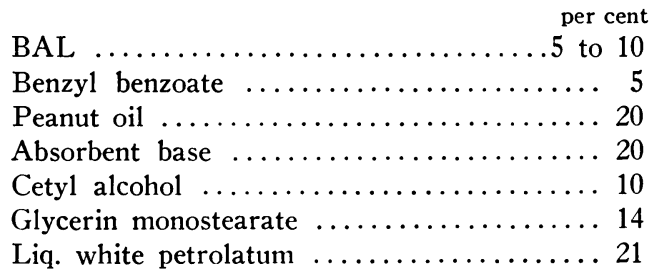

This ointment was readily miscible with the tears of the eye, and within a minute after instillation, became semifluid. It was non-toxic for the normal rabbit's and monkey's eyes, and showed therapeutic efficacy comparable to that of BAL in glycol solution.

Local toxicity of $B A L$. The tolerance of the normal cornea for BAL was determined on rabbits, monkeys and partially for humans (Table V). 
TABLE V

Tolerance of the normal eye to $0.1 \mathrm{ml}$. of $B A L$ solutions

\begin{tabular}{|c|c|c|c|c|c|}
\hline Species & BAL & Solvent & $\begin{array}{l}\text { Maximum } \\
\text { ocular } \\
\text { reaction }\end{array}$ & $\begin{array}{c}\text { Final } \\
\text { corneal } \\
\text { opacity }\end{array}$ & Days \\
\hline Rabbit & $\begin{array}{c}\text { per cent } \\
50 \\
\\
35 \\
25 \\
15 \\
10 \\
10 \\
5 \\
3 \\
3\end{array}$ & $\begin{array}{c}\text { Propylene } \\
\text { Glycol } \\
\text { P.G. } \\
\text { P.G. } \\
\text { P.G. } \\
\text { P.G. } \\
\text { Ointment } \\
\text { P.G. } \\
\text { P.G. } \\
\text { Water }\end{array}$ & $\begin{array}{c}\text { per cent } \\
67 \\
40 \\
20 \\
20 \\
5 \\
2 \\
5 \\
5 \\
2\end{array}$ & $\begin{array}{c}\text { per cent } \\
67 \\
13 \\
0 \\
0 \\
0 \\
0 \\
0 \\
0 \\
0\end{array}$ & $\begin{array}{l}7 \\
7 \\
2 \\
1 \\
0 \\
0 \\
0 \\
0 \\
0\end{array}$ \\
\hline Monkey & $\begin{array}{r}50 \\
35 \\
25 \\
15 \\
10 \\
10 \\
5\end{array}$ & $\begin{array}{c}\text { P.G. } \\
\text { P.G. } \\
\text { P.G. } \\
\text { P.G. } \\
\text { P.G. } \\
\text { Ointment } \\
\text { P.G. }\end{array}$ & $\begin{array}{r}42 \\
37 \\
22 \\
0 \\
2 \\
0 \\
0\end{array}$ & $\begin{array}{r}38 \\
21 \\
0 \\
0 \\
0 \\
0 \\
0\end{array}$ & $\begin{array}{l}7 \\
6 \\
4 \\
0 \\
0 \\
0 \\
0\end{array}$ \\
\hline $\begin{array}{r}\text { Human } \\
2 \text { eyes } \\
3 \text { eyes }\end{array}$ & $\begin{array}{r}10 \\
5\end{array}$ & $\begin{array}{l}\text { P.G. } \\
\text { P.G. }\end{array}$ & $\begin{array}{l}7 \\
5\end{array}$ & $\begin{array}{l}0 \\
0\end{array}$ & $\begin{array}{l}0 \\
0\end{array}$ \\
\hline
\end{tabular}

Toxic concentrations of BAL produced a sheetlike opacification of the superficial layers of the cornea which, if not unduly severe, sloughed off within a few days leaving clear stroma beneath. Rabbits, monkeys, and humans tolerated single instillations of BAL of concentrations from 3 to 10 per cent. BAL is temporarily irritating to the human eye, and produces an immediate stinging sensation, followed by blepharospasm, epiphora and conjunctival congestion.

Since an ocular lesion is almost completely prevented by the use of 2 drops of 5 per cent BAL within 2 minutes after exposure to Lewisite (see below), the more severe reactions which follow the use of higher concentrations must be attributed to the toxic action of the therapeutic agent. This damage produced by BAL can be distinguished clinically in an eye previously burned with Lewisite. It is noteworthy that the reactions produced by concentrations of BAL over 5 per cent in eyes previously exposed to Lewisite were more severe thun those produced by BAL on the normal cornea (Figure 3). This suggests that Lewisite lowers the tolerance of the cornea for BAL.

Penetrability of $B A L$. Direct iodometric titrations of the aqueous were made by Adler and his colleagues (9), who found an appreciable increase in the amount of sulfhydril-containing material 5 minutes after the instillation of BAL drops, or ointments, into the rabbit's eye. Such rapid penetrability of BAL is also demonstrated indirectly by its therapeutic effect on Lewisite-burned eyes.

Optimum concentrations of $B A L$ and techniques of application in the treatment of Lewisite burns. Although a single instillation of dilutions of BAL ranging from 25 per cent to 1 per cent prevented the development of any corneal opacity lasting more than 8 days, the use of 5 per cent BAL was

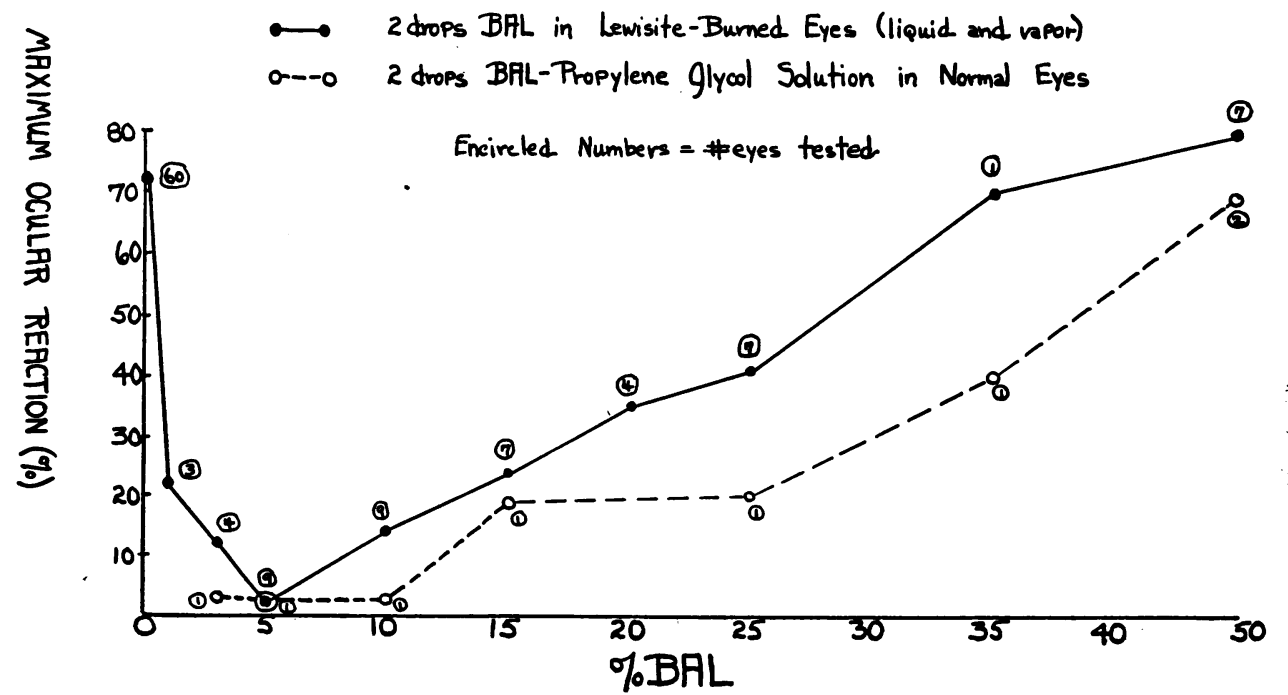

Fig. 3. Effect of Variation in Concentration of BAL on Reactions in Normal and Lewisite-burned RabBit Eyes 
found to be the optimum concentration which regularly produced spectacular cures of Lewisite burns (Table VI and Figures 4 and 5). Repeated in-

TABLE VI

Effect of variation in concentration of $B A L$ in the treatment of Lewisite burns of the rabbit's eye*

\begin{tabular}{c|c|c|c|c}
\hline \hline BAL solution & $\begin{array}{c}\text { Num- } \\
\text { ber of } \\
\text { eyes }\end{array}$ & $\begin{array}{c}\text { Maximum ocular } \\
\text { reaction }\end{array}$ & $\begin{array}{c}\text { Final corneal } \\
\text { opacity }\end{array}$ & $\begin{array}{c}\text { Num- } \\
\text { ber of } \\
\text { days } \\
\text { fol- } \\
\text { lowup }\end{array}$ \\
\hline per cent & & per cent & per cent & \\
25 & 1 & 45 & 0 & 6 \\
20 & 3 & 37 & 0 & 6 \\
15 & 4 & 23 & 0 & 4 \\
10 & 3 & 11 & 0 & 2 \\
5 & 5 & 4 & 0 & 1 \\
3 & 2 & 12 & 0 & 2 \\
1 & 1 & 20 & 0 & 2 \\
\hline Untreated & 42 & $74(\mathrm{SD}=8)^{* * *}$ & $69(\mathrm{SD}=14)$ & 7 \\
\hline
\end{tabular}

* Instillation of 2 drops of BAL in propylene glycol 2 minutes after application of $0.1 \mathrm{mgm}$. of liquid Lewisite. ** Instillation of 2 drops of propylene glycol has no influence on the severity of the Lewisite lesion.

*** $\mathrm{SD}=\mathrm{Standard}$ Deviation of the Mean.

stillations of BAL did not result in any additional therapeutic benefit. The use of 5 per cent BAL ointment was found to be at least equally as effective as glycol solutions of BAL in the treatment of both liquid and vapor burns. BAL was also found to be effective in the treatment of Lewisite burns of the monkey's eye. The effectiveness of BAL against Lewisite has also been demonstrated in many experiments by others (9 to 12 ).

Time limits during which BAL is effective. The instillation of BAL solution, or ointment, within 2 minutes after the end of exposure to Lewisite usually prevents the development of any significant conjunctival or corneal reaction. If treatment is delayed for 5 minutes, a transitory conjunctival and corneal reaction ensues and lasts a few days. Treatment instituted 10 minutes after exposure is definitely less effective, a mild to moderate corneal opacity persisting at the end of 7 days. The use of BAL within the first half hour lessens the severity of the ocular lesion when compared to control eyes, but permanent damage to the eye remains.

These findings are in agreement with the fact that irreversible histological changes are already detectable in the corneal stroma within 10 minutes after exposure to Lewisite, and are quite pronounced after 30 minutes. Also at the end of 30 minutes, some of the arsenic has already disappeared from the tissues, and so the benefit derived from decontaminating is diminished.

Persistence of arsenic in the cornea after the application of $B A L$

The quantity of arsenic remaining in the cornea at stated intervals after a standard exposure to Lewisite vapor was determined both for eyes treated with BAL, and for untreated controls (Table VII). Whereas a trace of arsenic was

TABLE VII

Influence of $B A L$ on the rate of disappearance of arsenic from the rabbit's cornea after Lewisite vapor burns

\begin{tabular}{c|c|c|c}
\hline \hline $\begin{array}{c}\text { Specimen } \\
\text { No. }\end{array}$ & BAL & $\begin{array}{c}\text { Time of ex- } \\
\text { cision of } \\
\text { cornea }\end{array}$ & $\begin{array}{c}\text { Gamma of } \\
\text { arsenic }\end{array}$ \\
\hline 1 & 0 & $2 \mathrm{~min}$. & 2.7 \\
2 & & & 2.9 \\
3 & & $30 \mathrm{~min}$. & 3.3 \\
4 & 1.2 \\
5 & $4 \mathrm{hr}$. & 1.9 \\
6 & & $24 \mathrm{hr}$. & 1.3 \\
7 & & 0.8 \\
\hline 8 & 2 drops of 5 per cent & $30 \mathrm{~min}$. & 0 \\
9 & BAL 2 min. after ex- & $4 \mathrm{hr}$. & 0 \\
10 & posure. & $24 \mathrm{hr}$. & 0 \\
\hline
\end{tabular}

demonstrated in the untreated corneas after 24 hours, those corneas treated with 5 per cent BAL showed no residual arsenic after 30 minutes. Thus the use of BAL facilitates the disappearance of arsenic from the tissues, probably by competing favorably with arsenic reversibly bound to the tissue components.

\section{Intravenous treatment of Lewisite burns of the eye with $B A L$}

Toxic doses of English BAL were administered intravenously to 2 rabbits in which $0.1 \mathrm{mgm}$. Lewisite had previously been instilled into the eyes. The conjunctival and, to some extent, the corneal reaction in these 2 animals was less than the average ocular reaction in control animals.

\section{SUMMARY AND CONCLUSIONS}

Exposure of the eye to small quantities of Lewisite liquid or vapor can produce a progressive 

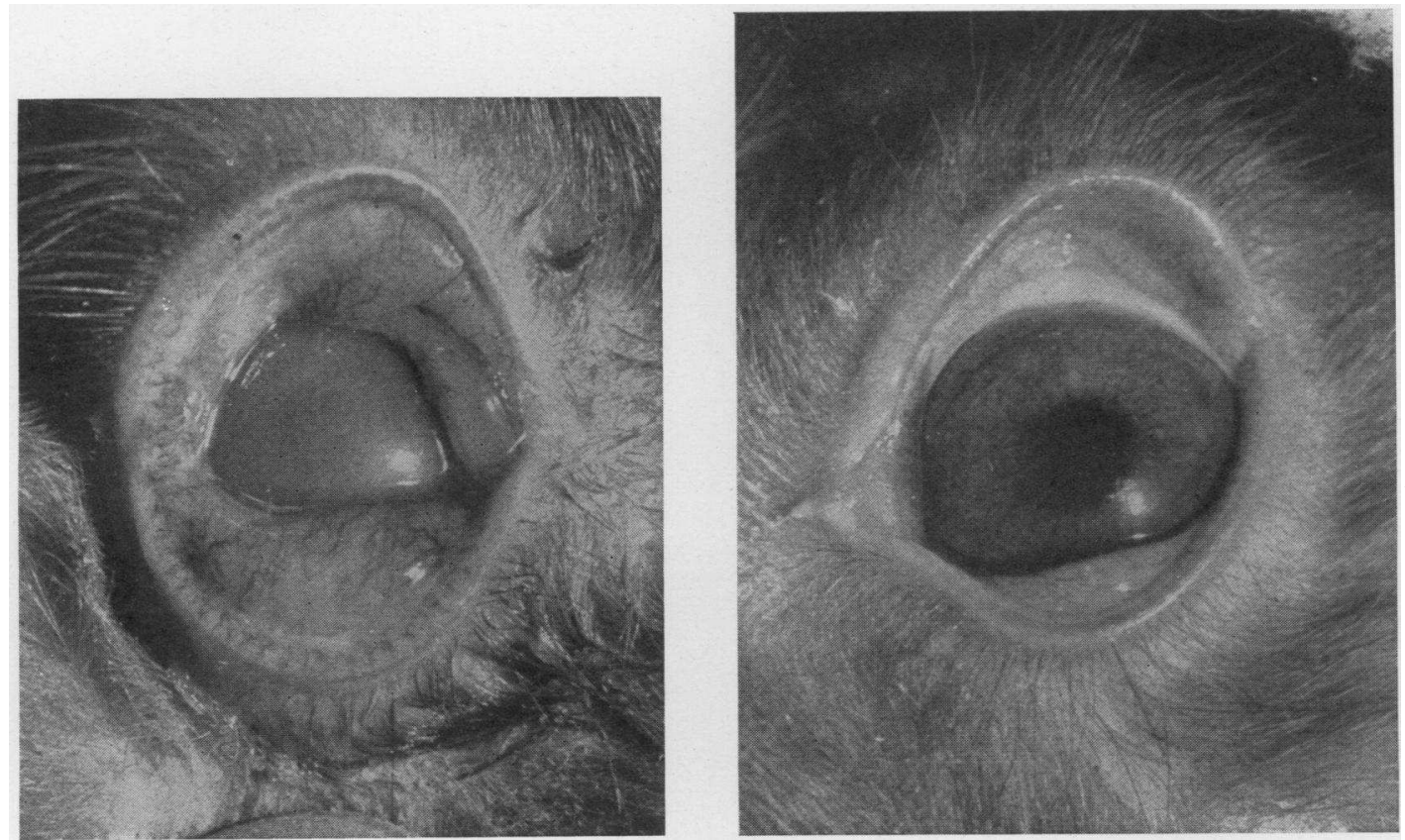

Fig. 4. Both Eyes Exposed 24 Hours Previously for 30 Seconds to Saturated Lewisite VAPOR AT $22^{\circ} \mathrm{C}$.

Right eye treated 2 minutes after exposure with $0.1 \mathrm{ml}$. of 5 per cent BAL in propylene glycol. Left eye is untreated.
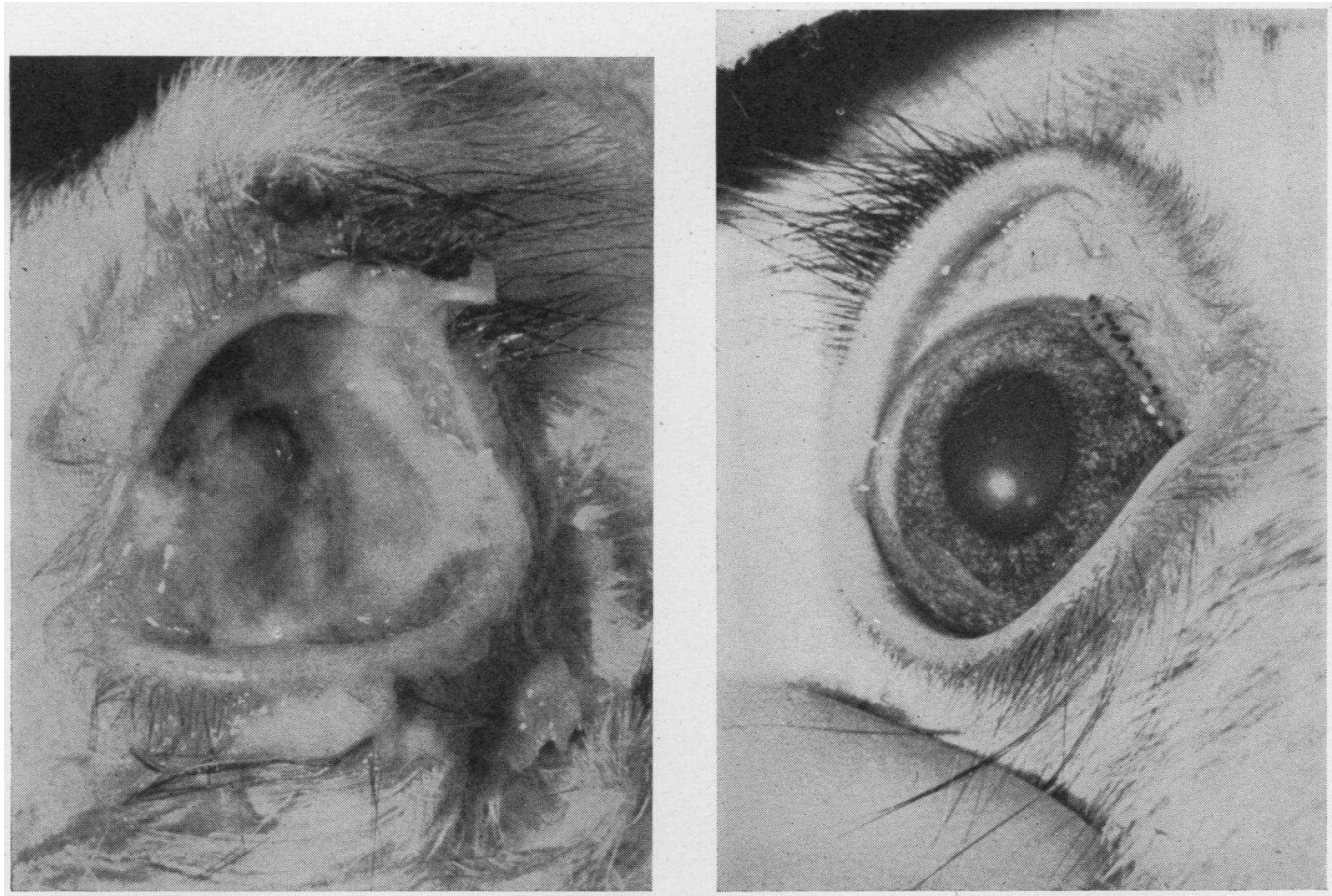

Fig. 5. Eyes Exposed and Treated in Same Manner as Those Shown in Figure 5, 4 Days After Exposure 
lesion of the cornea characterized by rapid tissue necrosis, marked edema and intense exudation. Lewisite is immediately hydrolyzed at the site of contact with the moist surface of the eye, liberating hydrochloric acid sufficient to produce a superficial corneal opacity. The more destructive characteristics of Lewisite burns can be produced by a neutral solution of Lewisite-oxide containing the trivalent arsenic. Within 2 to 4 minutes after exposure to Lewisite followed by closure of the lids, all toxic arsenical material disappears from the surface of the, cornea, and within 2 minutes can be demonstrated in the aqueous. Beginning at 10 minutes after exposure, and well marked at 30 minutes, irreversible histologic changes in the cornea can be detected.

A single instillation of 5 per cent BAL solution, or ointment, within 2 to 5 minutes after exposure to Lewisite effectively prevents the development of serious ocular lesions. This excellent therapeutic effect of BAL is due, in part at least, to its rapid penetration and withdrawal of toxic arsenical material from the tissues before irreversible histologic changes have developed.

\section{BIBLIOGRAPHY}

1. Peters, R. A., Stocken, L. A., and Thompson, R. H. S., British Anti-Lewisite. Nature, 1945, 156, 616.

2. Hughes, W. F., Jr., The treatment of Lewisite burns of the eye with BAL. To be published, Arch. Ophth.

3. Friedenwald, J. S., Hughes, W. F., Jr., and Herrmann, H., Acid burns of the eye. To be published, Arch. Ophth.

4. Scholz, R. O., Vapor chamber for the exposure of individual eyes at controlled temperatures. Personal communication.

5. Chaney and Magnuson, H. J., Ind. and Eng. Chem., Anal. Ed., 1940, 12, 691.

6. Eagle, H., Personal communication.

7. Eagle, H., Magnuson, H. J., and Fleischman, R., The systemic treatment of experimental arsenic poisoning with BAL. J. Clin. Invest., 1946, 25, 451.

8. Wexler, J., Eagle, H., Tatum, H. J., Magnuson, H. J., and Watson, E. B., The effect of BAL on the excretion of arsenic in normal subjects and after minimal exposure to arsenical smoke. J. Clin. Invest., 1946, 25, 467.

9. Adler, F. H., Leopold, I. H., Steele, W. H., and Crandall, A. S., Personal communication, 1943.

10. Mann, Ida, Personal communication, 1942.

11. Calvary et al., Personal communication.

12. Laughlin, R., Personal communication. 